\title{
The Use of Sweet Sorghum as a Feedstock for Ethanol Production
}

\author{
Lincoln Villi Gerke, Gabriela Lionço Zeferino, Armin Feiden \\ Mestrado em Engenharia de Energia na Agricultura, Universidade Estadual do Oeste do Paraná, Cascavel, Brazil \\ Email: Igerke68@agronomo.eng.br
}

Received 20 August 2014; revised 21 September 2014; accepted 22 October 2014

Academic Editor: Reginaldo Ferreira Santos, Universidade Estadual do Oeste do Paraná, Brasil

Copyright (C) 2014 by authors and Scientific Research Publishing Inc.

This work is licensed under the Creative Commons Attribution International License (CC BY). http://creativecommons.org/licenses/by/4.0/

(c) (i) Open Access

\begin{abstract}
The sweet sorghum is investigated as an alternative source in place of sugar cane for ethanol production. Its mass can be processed with the same machinery used in the processing of sugar cane, also offering a quantity of biomass (bagasse) similar in volume to the operation. The results obtained in the experiment showed that sweet sorghum cultivar Sugargraze produces ethanol lower than cane sugar ratio. The sugar content in this variety did not show the expected values in the first cut, which resulted in a short amount of ethanol, 740 liters per hectare. The material reached 3.7 meters and suffered no lodging, being easy to handle and cut with common shredder, same equipment used in the processing of corn. The conclusion of the study pointed to the viability of producing ethanol from sweet sorghum in commercial larger scales.
\end{abstract}

\section{Keywords}

Ethanol, Sweet Sorghum, Sugar Cane

\section{Introduction}

In 1983, the Alcohol Program (Decree 76.593, of 11/14/1975) has shown the "power” in the country: cars, vans, trucks, tractors ... everyone that used a motor was asked if he would work with the new fuel. Each new consumer of ethanol was identified as another hero for the country, for trusting in this technology that was coming and still causing a bit of fear. The times we saw people pushing their vehicle that did not work properly were not rare. The substitution of gasoline by ethanol in the period from 1976 to 2004 represented a savings of $\$ 61$ billion (dollars in December) or \$121 billion (with interest from the foreign debt). (O Estado de S. Paulo) 
http://www.biodieselbr.com/proalcool/historia/proalcool-historia-verdadeira.htm

Since then, the fear decreased, which is not yet reflected in solicitude as spending more for fuel. The economy still dictates the greater or lesser consumption of the product.

Several entities, whether public (Embrapa) or private (Monsanto, Ceres, Cargill, Canavialis), strive to evolve with knowledge and technologies to increase the use of fuel with other source. There are also independent producers, those who do not wait or have patience to wait for it to come ready, but want to participate in this path with personal achievements. Farmers who crave this energetic independence come out ahead, not caring comments, erroneous news, fines and losses; the important thing is to try.

(http://globotv.globo.com/rede-globo/globo-rural/v/agricultor-usa-sorgo-sacarino-para-produzir-etanol-em-fazen da-de-go/1954577/)

Ethanol has established itself as an energy source; the concern is to produce without affecting consolidated sectors. An exchange is not being sought. What is presented in this project is to discover something more from the consolidated technology.

The defense of the environment was seen as the last item to be analyzed throughout the production process, but the need to preserve natural resources and the constant appeal for cleaner production, promote the search for environmentally friendly and sustainable production processes.

In pursuit of sustainable development that has been maturing and consolidating its concept in all segments of society, prioritizing environmental issues and changing the way of acting, thinking and consequently producing, unveils new technologies in the pursuit of cleaner and more viable alternatives for the planet and for small farmers, freeing it from dependence on large corporations and turning it into an ally.

Regarding the production of ethanol from sweet sorghum, there are already data from experiments in some brandy and ethanol mills that demonstrate the real possibility of also using this feature as a renewable source (BENNETT; ANNEX, 2009).

The production of ethanol and sugar in Brazil is experiencing a time of optimism, due to a number of favorable factors. While the national economy recovers, with the increased consumption of sugar and fuels, including alcohol, the foreign market is also attractive and promising. However, Brazil is uncomfortable to be a major global producer of ethanol and cannot meet the demand itself, due to increased flex fuel vehicles generate a significant increase in the consumption of hydrous ethanol.

According to the green Paper "Para Uma Estratégia Européia de Segurançado Abastecimento Energético" ("Towards an European Strategy for Security of Energy Supply") there will be a requirement for incorporation of biofuels on the market, indicated by $20 \%$ of fossil fuels by 2020 [2].

There is a need to produce more ethanol and the reflection of that are found in some outputs:

- Increase the acreage of sugar cane;

- Improve the genetic quality of materials in the field;

- Optimize production period.

The area increase depends on economic incentives, because the planting of sugarcane is costly and holds the area for up to 8 years, productive period of sugarcane when conducted with cutting-edge technology. This residence time of the species in the field scares many producers. The genetic quality of materials is constantly survey, every period comes to market a range of new materials, but its use is intended for new or recovering areas. To optimize the production period we need material tailored to the criticism of Brazilian producing regions, which is the "off season" from February to April. This period, agreed to be the maintenance of the plants, is productive idleness because sugarcane is in the process of saccharification, goal of planting. If the product is harvested it will be less than expected in ethanol or sugar, burdening the entire industrial process. The sweet sorghum research is to cover this gap in the mills [2].

The sweet sorghum is resistant to dry spells and versatile in climatic factors, with high mass production, speed of production and easy installation and cultivation cycle, seems viable because the machines mills can process it the same way for sugar cane. Its stem also stores directly fermentable sugars, relatively similar to cane sugar and can be extracted in the same way by the same process [3]. It is not to invent but to optimize resources. The source already exists, but not yet exploited. With this study we have data that provides information about its viability as an energy source, gains, advantages and disadvantages, and the possibility of acceptance and deployment in a sustainable manner, for the small and medium farmers.

There are other materials, but this is shown perfectly adaptable to an existing process, proven efficient and amenable to insertions of search technology process, and what this research is sought. 


\section{Material and Methods}

The experiments cultivation of sweet sorghum were performed in Prof. Dr. Antonio Carlos dos Santos Pessoa Experimental Station in the city of Marechal Candido Rondon, Linha Guará, rural area. Sweet sorghum hybrid ADV 2010 was planted, the seeds were provided by Advanta Company. The planting spacing was $0.70 \mathrm{~m}$ between rows and density ranged 5 - 7 plants per meter, in an area of $2500 \mathrm{~m}^{2}$ (Figure 1 ).

In the agricultural year 2013/2014, the plantation was on September 17, that occured after the period of planting corn for silage. Cultural practices performed in maize have been extended to the portion of sorghum, as follows, were applications of fertilizer in tillage, herbicide and cover with nitrogen, conducted at recommended for the corn crop seasons in the region (Table 1).

There was accompanying the sucrose content of the stem during the development, which was noted (table below) in the course of its development and there was the issue of the panicle to indicate mowing season (Table 2).

The cutting occurred manually with 142 days after germination of the same, on January 31, 2014. The yield was $6.9 \mathrm{~kg}$ of biomass per meter, exceeding 98 tonnes/ha (projected) and was processed on the same day. The transport of biomass was carried out by a tractor and cart, to the location of the press to process the material (a small press cane was used), and the broth collected manually fed to a $600 \mathrm{l}$ container for transport to the laboratory in technology of biofuels from the Federal University of Paraná in Palotina, state of Paraná. Three hundred and sixty liters were stored and the fermentation was accompanied by the trainee, who mixed 325 grams of yeast to the product. On the 2nd day the wine was distilled to prove the numbers listed on measuring instruments of sugar and ethanol (Figure 2).

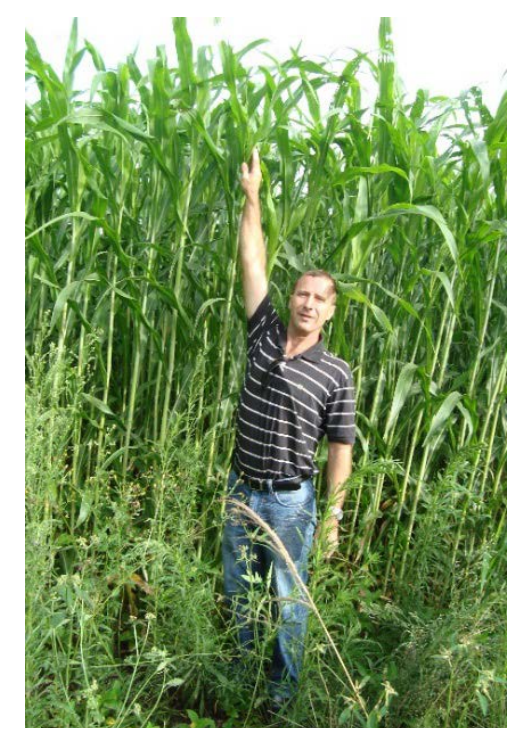

Figure 1. Material field.

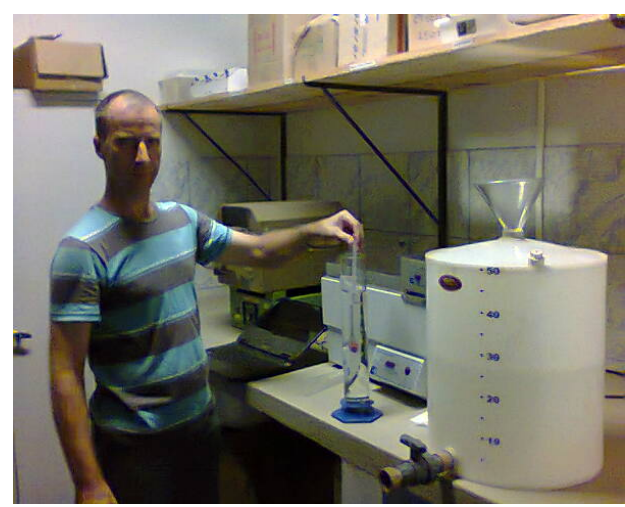

Figure 2. In laboratory. 
Table 1. Using materials.

\begin{tabular}{ccc}
\hline Planting September $17^{\text {th }}, 2013$ & Herbicide October $20^{\text {th }}, 2013$ & Coverage November $11^{\text {th }}, 2013$ \\
\hline $\begin{array}{c}5 \mathrm{~kg} \text { of seeds } 200 \mathrm{~kg} \mathrm{08-20-20} \\
(\mathrm{NPK}) / \mathrm{ha}\end{array}$ & Atrazine $0.4 \mathrm{~kg} / \mathrm{ha}$ & $100 \mathrm{~kg}$ Ammonium Sulphate/ha \\
\hline
\end{tabular}

Table 2. Dates of events.

\begin{tabular}{|c|c|c|c|c|c|c|}
\hline Date & $\begin{array}{c}\text { August } 19^{\text {th }}, \\
2013\end{array}$ & $\begin{array}{c}\text { November } 13^{\text {th }} \text {, } \\
2013\end{array}$ & $\begin{array}{c}\text { November } 20^{\text {th }} \text {, } \\
2013\end{array}$ & $\begin{array}{c}\text { December } 30^{\text {th }} \text {, } \\
2013\end{array}$ & $\begin{array}{c}\text { January } 7^{\text {th }}, \\
2014\end{array}$ & January $11^{\text {th }}, 2014$ \\
\hline Brix & Nihil & $3 \%$ & $3 \%$ & $7 \%$ & $6 \%$ & $4 \%$ \\
\hline Date & 18.01.2013 & 24.01 .2013 & 27.01.2013 & & In the laboratory & \\
\hline Brix & $10 \%$ & $10 \%$ & $10 \%$ & & $9.6 \%$ & \\
\hline
\end{tabular}

\section{Results and Discussion}

By pressing were removed 28\% of the total mass of the sorghum broth, or each of the biomass was $6.9 \mathrm{~kg} 2.0 \mathrm{~kg}$ a portion removed in broth. The reading of the solids content in the product was 9.60 BRIX, the ebulliometer and analysis revealed a content of $2.6 \%$ ethanol in wine.

\begin{tabular}{cccc}
\hline Harvested biomass & Sugarcane juice & Brix of syrup & Volume ethanol removed (800 - 940) \\
\hline $1285.75 \mathrm{~kg}$ & $360 \mathrm{l}$ & $9.6 \%$ & $13.5 \mathrm{l}$ \\
\hline
\end{tabular}

Distillation of the 360 liters of wine started at 8:00 h and went until noon, providing ethanol 80 - 940 GL, resulting in 13.5 liters collected in distiller.

Studies show that factors such as genotype, environment, location, climate and environmental interactions act significantly in the final qualities of grainsorghum and stem. The binding of the chemical composition of the grain and its physical properties strongly interferes in ethanol production, in other words, the genotype and the environment influences the yield. Evidence shows that the rate of conversion to ethanol increases with high starch in the grain without finding a linear link between these two factors. Although sorghum is drought tolerant when planted early in the season it shows a higher rate of fermentable sugars and higher purity of broth, it is perceived by the greater brightness and photoperiod the beginning of the season (PEDROSO et al., 2010.)

Planting occurred on 17 September, beginning of the rainy season, its biomass yield reached expected, but the sugar content fell short of the data published by research. Projecting the yield in pure ethanol is reached in little more than 740 liters per hectare, low volume when compared to sugarcane that reaches 6000 liters per hectare (Table 3).

These data need to be confirmed in further research, as these materials, as well as sugar cane, are very sensitive to even the most subtle climate change. Differences in production values in sorghum are observed even in years of similar climates [4].

\section{Conclusions}

The sugar content in this variety did not show the expected values in the first cut, which resulted in a short amount of ethanol, 740 liters per hectare. The pressing of the material can be improved, since it was not made with suitable equipment, leaving enough of the culture broth in stems, and this would increase the final broth volume, producing more ethanol per hectare. The withdrawal was $28 \%$ and can reach $60 \%$ using proper equipment and set to this material, which would increase the amount of ethanol to interesting levels [1].

The material grew satisfactorily, as described, reaching 3.7 meters and suffered lodging, being easy to handle and cut with common shredder, same equipment used in the processing of corn. And the 2nd cut, which would be held with the regrowth, has not been studied, but it will be later.

The study showed that it is possible to produce ethanol from sweet sorghum at larger scales, the viability of 
Table 3. Projection.

\begin{tabular}{cccc}
\hline \multicolumn{2}{c}{ Area } & \multicolumn{2}{c}{ Projection } \\
\hline $130.4 \mathrm{~m}^{2}$ & $360 \mathrm{l}$ & $10,000 \mathrm{~m}^{2}$ & $27607.36 \mathrm{l}$ \\
$1285.75 \mathrm{~kg}$ & $13.5 \mathrm{l} \mathrm{etanol}(800-940)$ & $98600.0 \mathrm{~kg}$ & 1035.2 l ethanol (800 - 940) \\
\hline
\end{tabular}

this achievement should still be analyzed in greater detail.

\section{References}

[1] Lourenço, M.E.V., et al. (2007) Potencialidades do sorgo sacarino [Sorghum bicolor (L.) Moench] para a produção sustentável de bioetanol no Alentejo. Rev. de Ciências Agrárias (Online), 30, 103-110.

[2] Moench, L., et al. (2012) Influência do arranjo de plantas no desempenho produtivo de sorgo sacarino (Sorghum bicolor (L.) Moench), em Sete Lagoas-MG. In: Congresso Nacional de Milho e Sorgo, Ed., Águas de Lindóia. Diversidade e inovações na era dos transgênicos: Resumos expandidos, Instituto Agronômico, Campinas; Associação Brasileira de Milho e Sorgo, Sete Lagoas, 2282-2289.

[3] Pedroso, S., et al. (2010) Avanços tecnológicos na obtenção de etanol a partir de sorgo sacarino (Sorghum bicolor (L.) Moench). TECNO-LÓGICA, Santa Cruz do Sul, 14, 69-75.

[4] Ibrahim, A.A., Ati, F.O. and Adebayo, A.A. (2011) Effect of Climate on the Growth and Yield of Sorghum (Sorghum bicolor) in Wailo, Ganjuwa Local Government Area, Bauchi State. Research Journal of Environmental and Earth Sciences, 3, 469-472. 
Scientific Research Publishing (SCIRP) is one of the largest Open Access journal publishers. It is currently publishing more than 200 open access, online, peer-reviewed journals covering a wide range of academic disciplines. SCIRP serves the worldwide academic communities and contributes to the progress and application of science with its publication.

Other selected journals from SCIRP are listed as below. Submit your manuscript to us via either submit@scirp.org or Online Submission Portal.
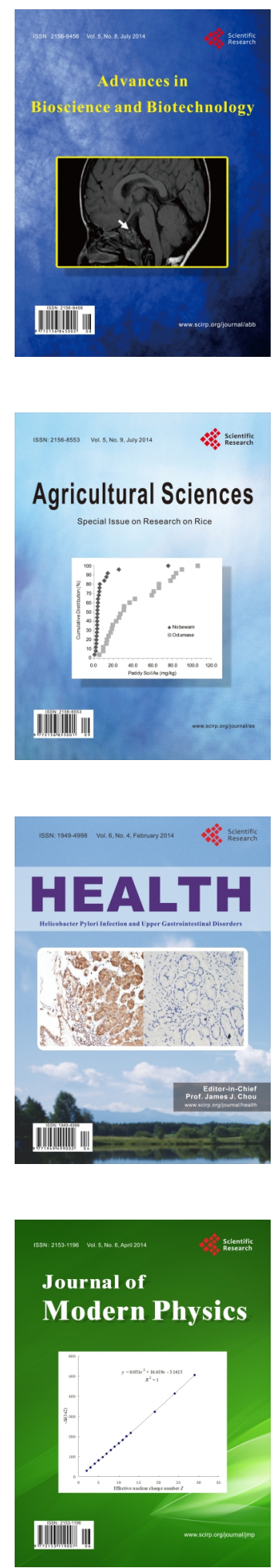
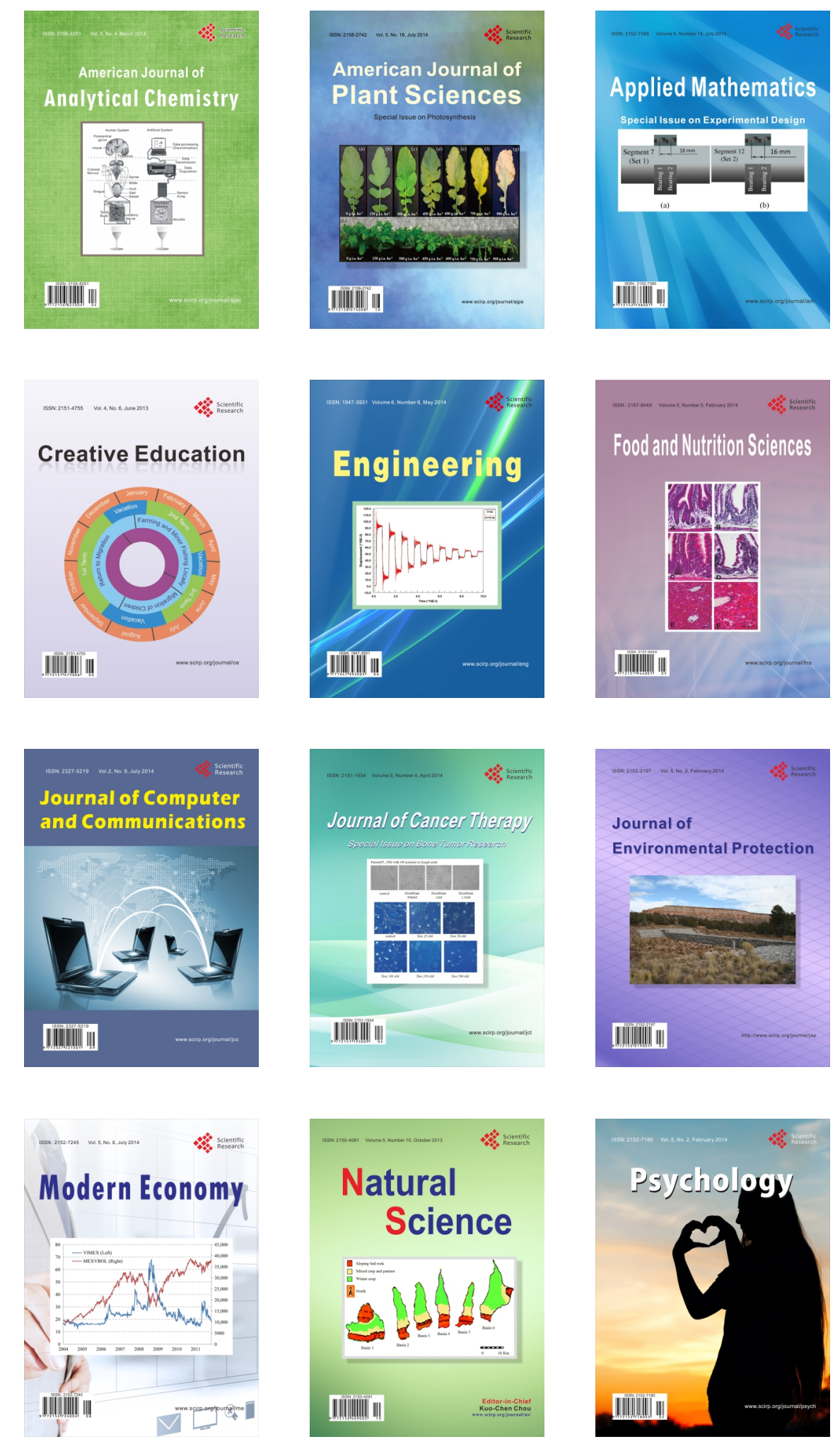